\title{
Role of Glia in the Regulation of Gonadotropin-Releasing Hormone Neuronal Activity and Secretion
}

\author{
Ariane Sharif Marc Baroncini Vincent Prevot \\ INSERM, Jean-Pierre Aubert Research Center, Development and Plasticity of the Postnatal Brain, Unit 837, and \\ UDSL, School of Medicine, Lille, France
}

\section{Key Words}

Gonadotropin-releasing hormone neuron - Astrocyte . Tanycyte $\cdot$ Preoptic area $\cdot$ Median eminence $\cdot$ Puberty . Estrous cycle

\begin{abstract}
Gonadotropin-releasing hormone $(\mathrm{GnRH})$ neurons are the final common pathway for the central control of reproduction. The coordinated and timely activation of these hypothalamic neurons, which determines sexual development and adult reproductive function, lies under the tight control of a complex array of excitatory and inhibitory transsynaptic inputs. In addition, research conducted over the past 20 years has unveiled the major contribution of glial cells to the control of GnRH neurons. Glia use a variety of molecular and cellular strategies to modulate $\mathrm{GnRH}$ neuronal function both at the level of their cell bodies and at their nerve terminals. These mechanisms include the secretion of bioactive molecules that exert paracrine effects on GnRH neurons, juxtacrine interactions between glial cells and GnRH neurons via adhesive molecules and the morphological plasticity of the glial coverage of GnRH neurons. It now appears that glial cells are integral components, along with upstream neuronal networks, of the central control of GnRH neuronal function. This review attempts to summarize our current knowledge of the mechanisms used by glial cells to control $\mathrm{GnRH}$ neuronal activity and secretion.
\end{abstract}

Copyright $\odot 2013$ S. Karger AG, Basel

\section{KARGER}

(c) 2013 S. Karger AG, Basel

0028-3835/13/0981-0001\$38.00/0

E-Mail karger@karger.com

www.karger.com/nen

\section{Introduction}

Reproductive function is centrally controlled by a group of specialized neurosecretory neurons that produce the neuropeptide gonadotropin-releasing hormone $(\mathrm{GnRH})$. These neurons, which in rodents are located in the preoptic region of the hypothalamus, send their neurosecretory axons to the median eminence of the hypothalamus, where $\mathrm{GnRH}$ is released into pituitary portal blood vessels for delivery to the anterior pituitary gland. Within the adenohypophysis, GnRH elicits the secretion of luteinizing hormone (LH) and follicle-stimulating hormone, which in turn promote gonadal development and support reproductive physiology. While GnRH neurons are in place within the hypothalamus at birth, they are not mature until puberty. From this point on, in females, the coordinated and timely activation of $\mathrm{GnRH}$ neurons on the day of proestrus triggers a peak in the release of $\mathrm{GnRH}$ into the portal blood, which in turn induces a surge in $\mathrm{LH}$ and, subsequently, ovulation [1].

The activity of GnRH neurons is finely regulated by a complex network of excitatory and inhibitory transsynaptic inputs [2-4]. In addition to their neuronal afferents, GnRH neurons are in close contact with glial cells (fig. 1). Astrocytes enwrap GnRH perikarya, while tanycytes, which are specialized ependymoglial cells, interact selectively with GnRH axons and terminals at the level of the median eminence [5-13]. A growing body of evidence

Ariane Sharif or Vincent Prevot

INSERM U837

Place de Verdun

FR-59045 Lille Cedex (France)

E-Mail ariane.sharif @ inserm.fr or vincent.prevot@inserm.fr 
now suggests that glial cells are far from being passive structural elements, and actually play a critical role in the regulation of GnRH neuronal activity and secretion.

This review will summarize our current knowledge regarding the mechanisms used by glial cells to regulate GnRH function. While astrocytes may also be implicated in the early development of the GnRH system $[14,15]$ and in the control of neuronal circuits regulating the activity of GnRH neurons, notably in the arcuate nucleus (see [16] for review), here we will focus only on the direct molecular and cellular interactions that occur between glial cells and $\mathrm{GnRH}$ neurons during postnatal development.

\section{Cellular and Molecular Mechanisms Involved in the Glial Control of GnRH Neuronal Activity and Secretion}

Glial cells use a variety of molecules and strategies to modulate distinct aspects of GnRH neuronal physiology. These mechanisms include the secretion of paracrine factors, juxtacrine interactions between glial cells and $\mathrm{GnRH}$ neurons via adhesive molecules, and the structural remodeling of the glial coverage of GnRH neurons.

\section{Glial Cell-Derived Paracrine Factors Involved in}

Communication between Glia and GnRH Neurons

The best-characterized glial cell-derived factors that act on $\mathrm{GnRH}$ neurons in a paracrine manner to modulate their function are prostaglandin $\mathrm{E}_{2}$ (PGE2) and peptide growth factors of the transforming growth factor (TGF) $\beta$ family (fig. 2, 3).

\section{Glia-to-GnRH-Neuron Communication via PGE2}

PGE2 is a phospholipid-derived molecule that has long been known to be a potent stimulator of the GnRH system (reviewed in [17]). In the hypothalamus, glial cells, both astrocytes and tanycytes, have been identified as primary sources of PGE2.

A highly potent signaling system capable of triggering PGE2 release from hypothalamic astrocytes involves the epidermal growth factor (EGF)-related family of peptides and their receptors, the erbB tyrosine kinases [18]. In rodent hypothalamic astrocytes, which express 3 of the 4 erbB receptors, namely erbB1 (or EGF receptor; EGFR), erbB2 and erbB4 [19-21], exposure to transforming growth factor-alpha (TGFa) and the neuregulins (NRGs) activates erbB1/erbB2 and erbB4/erbB2 heterodimers, respectively, leading to the release of PGE2, which in turn stimulates the release of $\mathrm{GnRH}$ from $\mathrm{GnRH}$-producing cells and median eminence explants [20-23]. Importantly, as $\mathrm{GnRH}$ neurons have been shown to lack erbB receptors $[21,24,25]$, the stimulatory effect of EGF family peptides on $\mathrm{GnRH}$ release necessarily involves a glial intermediary. Moreover, this astrocyte-to-neuron signaling pathway has been shown to be set in motion by glutamate. The concomitant activation of ionotropic and metabotropic glutamate receptors located on astroglial cells stimulates erbB
Fig. 1. Glial cells interact closely with both GnRH neuronal cell bodies and processes. Fluorescent photomicrographs of the adult mouse hypothalamus showing GnRH (a-k, green) and GFAP (inset in a, green) immunoreactivity, and expression of the glia-specific protein GLAST (red). To visualize glial cells, transgenic mice expressing the tamoxifen-inducible CreERT2/loxP system under the control of the sodium-dependent glutamate/aspartate transporter (Glast) promoter (Tg(Glast-CreERT2)45-72 line [108]) were crossed with mice expressing the ACTB-tdTomato reporter (http://jaxmice.jax. org/strain/007676.html). Adult bigenic mice were subcutaneously injected with tamoxifen (4 $\mathrm{mg}$ from a stock of $20 \mathrm{mg} / \mathrm{ml}$ in 1:9 ethanol/sunflower oil), sacrificed two days later and subjected to immunofluorescent detection of GnRH or GFAP following previously described procedures [109]. a-d Within the preoptic area, GnRH neuronal cell bodies morphologically interact with astrocytes. Inset in a While the cell body and the highly branched, 'bushy', structure of astrocytes can be visualized using GLAST-Tomato mice (red), GFAP immunoreactivity (green) only reveals the cell body and the major cell processes. c (high-magnification view from b), d GnRH neurons, astrocytes (arrowheads) and blood-brain barrier capillaries (asterisks) make intimate contacts. Little arrows in c point to an astrocytic process that contacts a GnRH neuron. Hoechst-stained nuclei are shown in $\mathbf{d}$ (white). e Low-magnification view of the organum vasculosum of the lamina terminalis (OVLT) after counterstaining of the nuclei with Hoechst (white). The boxed area indicates the site of the image shown in f. f-h In the OVLT, a circumventricular organ where GnRH neurons were recently shown to extend highly branched dendritic trees [110], GnRH neurites exhibit a strong association with tanycyte-like elements [111]. $\mathbf{g}, \mathbf{h}$ High magnification views from $\mathbf{f}$. Arrowheads point to tanycyte-like cell bodies abundantly apposed by $\mathrm{GnRH}$ dendritic elements. $\mathbf{i}$ Low-magnification view of the median eminence (ME) after counterstaining of nuclei with Hoechst (white). Boxed areas indicate the site of the images shown in $\mathbf{j}$ and $\mathbf{k}$. j, $\mathbf{k}$ Tanycytes, whose cell bodies line the ventricular wall (arrowheads), send processes toward the capillaries (Cap) of the pituitary portal blood system. $\mathrm{GnRH}$ axonal fibers are closely apposed to tanycytic processes in the external zone of the ME (arrows). $3 \mathrm{~V}=$ Third ventricle; $\mathrm{ARH}=$ arcuate nucleus of the hypothalamus; $\mathrm{DMH}=$ dorsomedial hypothalamus; $\mathrm{MS}=$ medial septum; oc $=$ optic chiasm; $\mathrm{VMH}=$ ventromedial hypothalamus. Scale bars: $200 \mu \mathrm{m}(\mathbf{e}, \mathbf{i}), 50 \mu \mathrm{m}(\mathbf{f}), 25 \mu \mathrm{m}$ (main panel in $\mathbf{a}, \mathbf{b}, \mathbf{j}, \mathbf{k}$ ) and $20 \mu \mathrm{m}$ (inset in $\mathbf{a}, \mathbf{c}, \mathbf{d}, \mathbf{g}, \mathbf{h}$ ). 


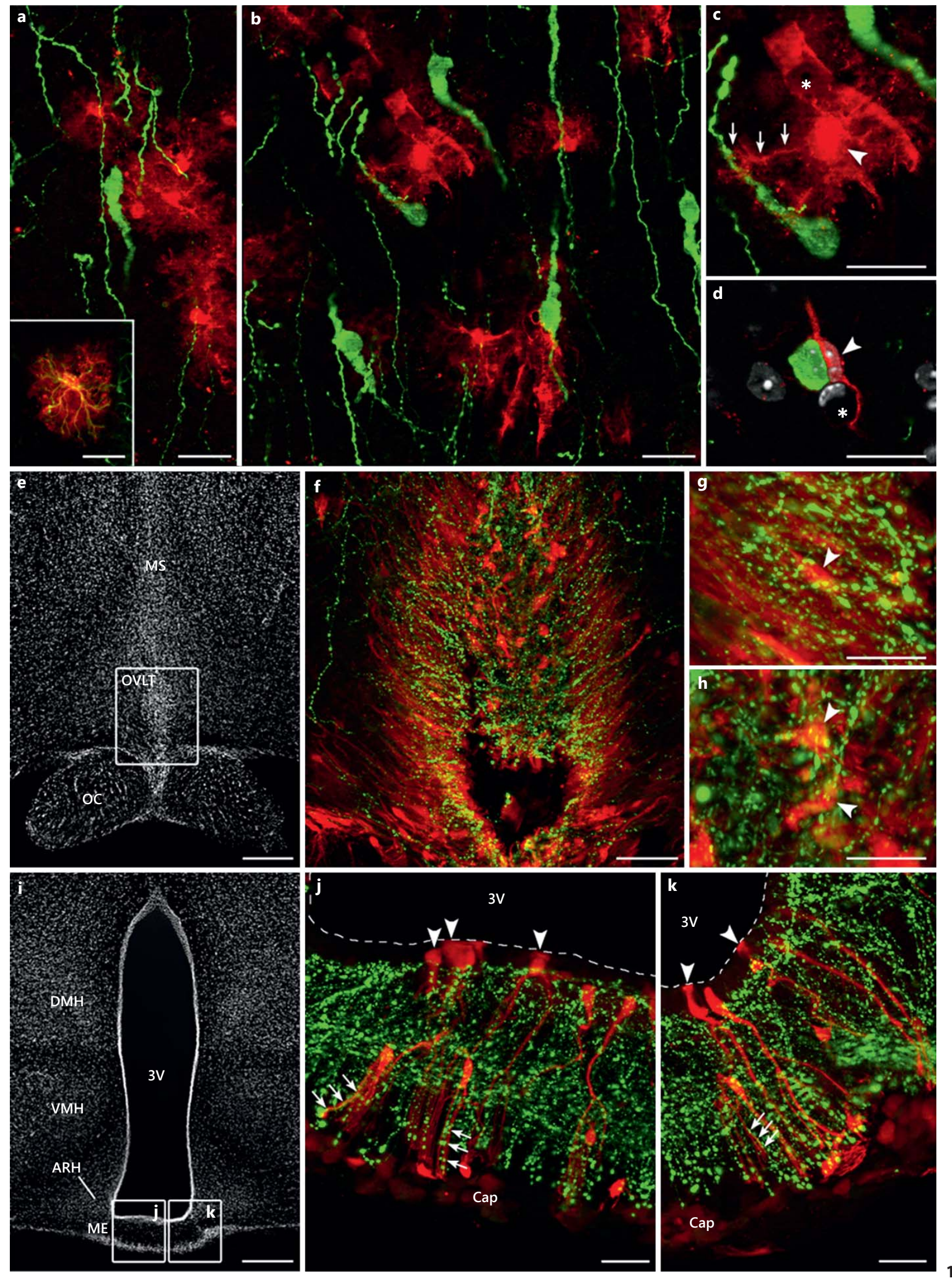




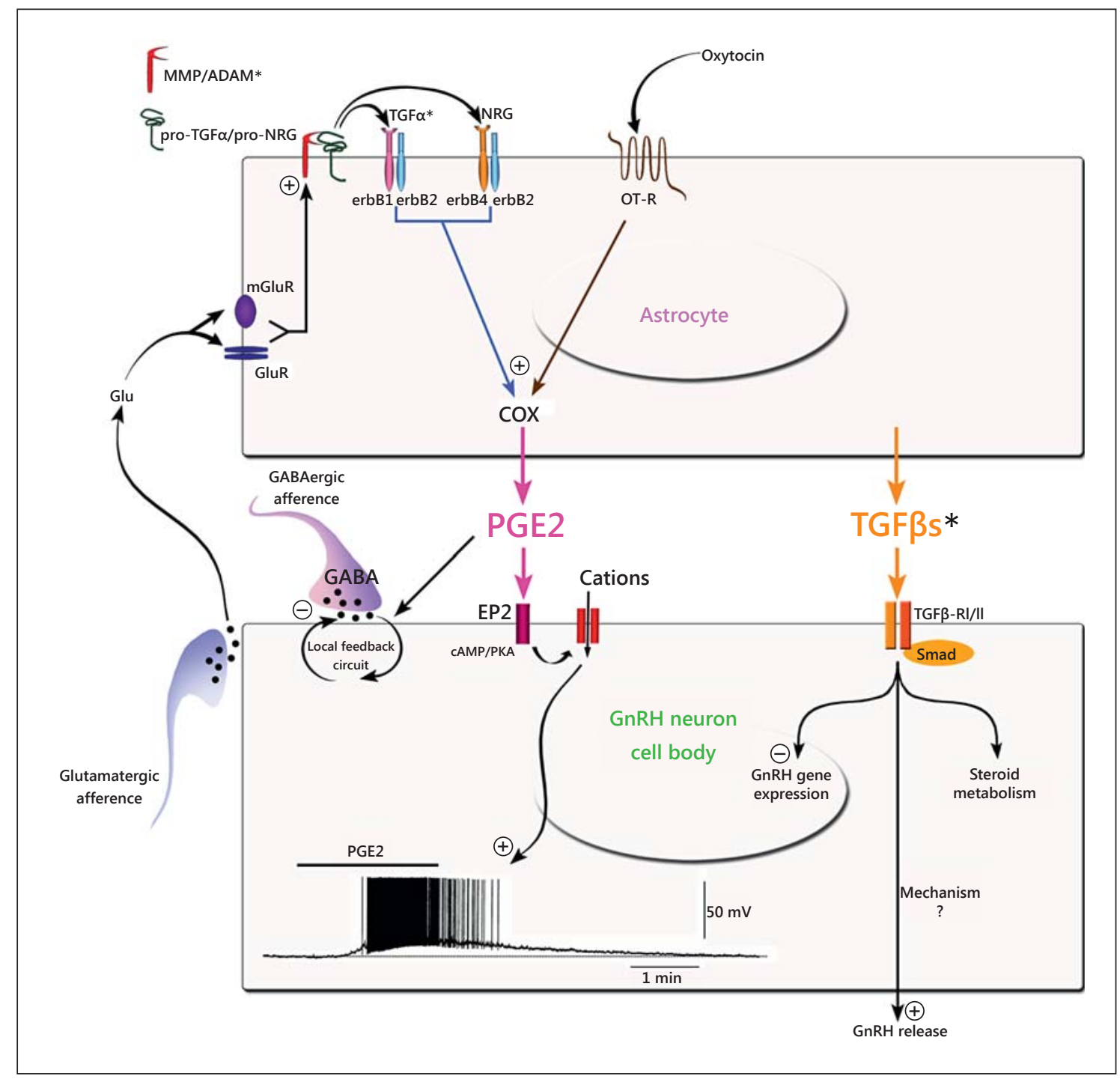

Fig. 2. Glia-to-GnRH-neuron paracrine communication at the level of GnRH cell bodies. Astrocytes modulate GnRH function via the release of PGE2 (left) and growth factors of the TGF $\beta$ family (right). In hypothalamic astrocytes, two signaling systems have been shown to trigger PGE2 release, the glutamate/EGF peptides/ erbB signaling system and the oxytocinergic signaling system. The concomitant activation of metabotropic (mGluR) and AMPAtype glutamatergic receptors (GluR) in astrocytes by neuronally released glutamate (Glu) stimulates the activity of zinc-dependent MMP of the ADAM (a disintegrin and metalloproteinase) family and promotes the recruitment of erbB1, erbB4, and their pro-ligands to the cell membrane. MMPs catalyze the release of mature TGFa and NRG peptides from their respective membrane-anchored precursors, pro-TGF $\alpha$ and pro-NRG. In particular, the metalloproteinase ADAM17, also known as TACE is involved in the processing of pro-TGFa. TGFa and NRG then activate erbB1/ erbB2 and erbB4/erbB2 heterodimers, respectively, leading to the production of PGE2 by COX and its subsequent release from astrocytes $[19,20,22,26]$. PGE2 is also released upon the activation of the $\mathrm{G}$ protein-coupled oxytocin receptors (OT-R), which are located on hypothalamic astrocytes. Notably, oxytocin is less potent than TGFa in eliciting PGE2 release [33]. Astrocyte-derived PGE2 activates EP2 receptors (EP2) and the subsequent mobilization of a cAMP/PKA pathway in GnRH neurons, leading to the activation of a nonselective cation current that promotes membrane depolarization and initiates spike firing [44]. Moreover, the depolarization of GnRH neurons induces the short-term inhibition of their GABAergic afferents via a local feedback circuit that requires the presence of astrocyte-derived PGE2 [47]. Astrocytes also release TGF $\beta$ s $[39,48-51]$, which activate type I (TGF $\beta-R I)$ and type II (TGF $\beta$-RII) serine/threonine kinase TGF $\beta$ receptors located on GnRH neuronal cell bodies $[58,59]$. These receptors use Smad proteins as intracellular transducers to regulate transcriptional events (for review see [112]). In GnRH neurons, TGF $\beta$ s affect steroid metabolism, downregulate GnRH mRNA expression, and stimulate $\mathrm{GnRH}$ release $[50-55,58]$ via an as yet unidentified mechanism thought to occur at the level of GnRH perikarya. Asterisks indicate the molecular components shown to be positively regulated by gonadal steroids in primary cultures of hypothalamic astrocytes (see main text for details). 


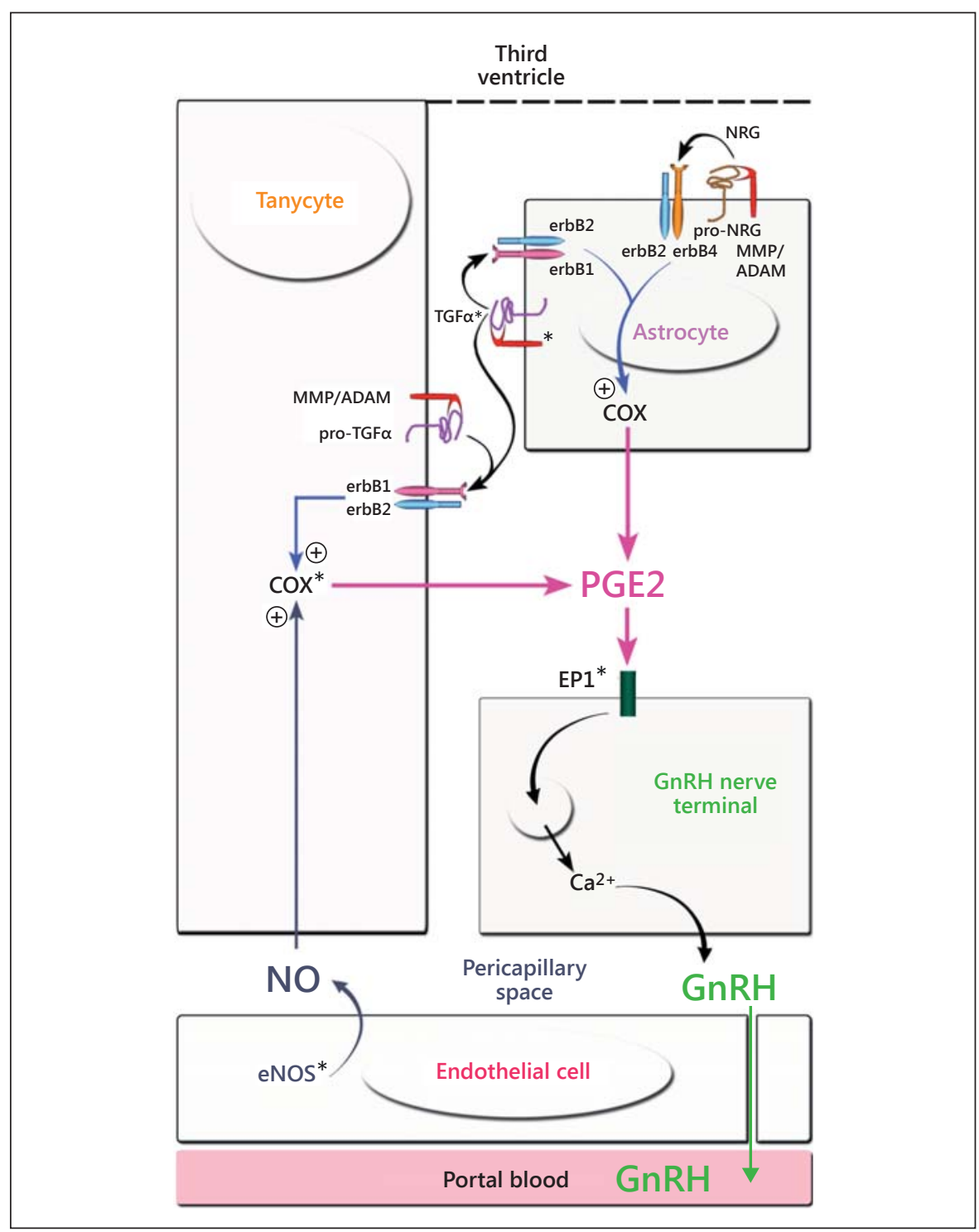

Fig. 3. Glia-to-GnRH-neuron paracrine communication at the level of the GnRH nerve terminals. Within the median eminence, $\mathrm{TGF} \alpha$, which is produced by both tanycytes and astrocytes $[27,39$, 79], stimulates erbB1/erbB2 heterodimers in tanycytes, leading to the production of PGE2 [39]. The release of PGE2 by tanycytes is also promoted by a cell-cell mechanism involving the endothelial cells of the fenestrated capillaries of portal blood vessels. Upon activation of eNOS, endothelial cells release the gaseous messenger nitric oxide (NO), which rapidly diffuses to neighboring tanycytes to stimulate the enzymatic activity of COX and the subsequent release of PGE2 [40, 41]. Astrocytes are also abundant within the median eminence and provide another source of glial paracrine factors (see legend of figure 2 for details). The importance of median eminence astrocytes in eliciting $\mathrm{GnRH}$ release via the production of PGE2 is demonstrated by experiments performed on median eminence explants from transgenic mice with deficient erbB4 signaling in astrocytes. Indeed, at the level of the median eminence, erbB4 is only present in astrocytes [20] and its disruption abrogates the NRG-induced release of GnRH from median emi- nence explants, an effect that is reversed by exogenous PGE2 [21]. Notably, since mechanistic insights into the release of paracrine factors from hypothalamic astrocytes were obtained using in vitro preparations of isolated cells from whole hypothalami, it is not presently known whether astrocytes of the preoptic area differ from those of the median eminence. Moreover, while TGF $\beta$ s act as glia-derived paracrine factors in the preoptic area due to the presence of their receptors on GnRH cell bodies (fig. 2), they are unable to do so in the median eminence since $\mathrm{GnRH}$ nerve terminals do not express TGF $\beta$ receptors [58]. Upon its release, glia-derived PGE2 is thought to stimulate EP1 receptors (EP1) on GnRH nerve endings, leading to the mobilization of intracellular calcium stores and the subsequent release of GnRH from neurosecretory terminals $[42,45,46]$. Asterisks indicate the molecular components shown to be positively regulated by gonadal steroids in primary cultures of astrocytes, tanycytes, endothelial cells and in the GnRHproducing cell line GT1-1. Note that the stimulatory effect of estradiol on EP1 expression in GT1-1 cells is not direct but requires astrocytic mediation (see main text for details). 
signaling by favoring the redistribution of TGFa-erbB1 and NRG-erbB4 complexes to the cell membrane and the subsequent metalloproteinase (MMP)-dependent transactivation of receptors $[19,26]$. This link between glutamate receptors and erbB signaling in astrocytes could represent a mechanism used by the neuroendocrine brain to coordinate the enhanced glutamatergic neurotransmission and glial back-signaling to $\mathrm{GnRH}$ neurons required for the timely onset of mammalian puberty [2]. The in vivo significance of the EGF signaling pathway in controlling $\mathrm{GnRH}$ function is suggested by experiments showing that the expression of TGFa, erbB1, erbB2, erbB4 and the enzymatic activity of tumor necrosis factor- $\alpha$-converting enzyme (TACE), a metalloproteinase involved in the ectodomain shedding of TGF $\alpha$ and the subsequent activation of erbB1 in response to glutamatergic inputs [26], increase in the hypothalamus at the time of puberty [20,24, 26-28]. Moreover, the in vivo deregulation of TGFa/ erbB1 [23, 27, 29-32] or erbB2 signaling [20], or the inhibition of TACE activity [26], perturbs the onset of female puberty. The crucial role of astrocytic erbB signaling in the control of reproductive function has been demonstrated in transgenic mice expressing a dominant-negative erbB4 receptor in astrocytes, which selectively blocks the liganddependent activation of erbB4 and erbB2 receptors in these cells [21]. Mice carrying the transgene exhibit delayed sexual maturation and diminished reproductive capacity in early adulthood. Moreover, erbB1 and erbB4 work in a coordinated fashion to control reproductive function, since mutant mice in which both erbB1 and erbB4 signaling are disrupted exhibit further delays in the onset of puberty and a striking decrease in reproductive capacity in adulthood in comparison to mice deficient in either erbB1 or erbB4 alone [23].

Another environmental cue capable of triggering the release of PGE2 from hypothalamic astrocytes is oxytocin [33]. Oxytocin is a potent stimulator of GnRH secretion from hypothalamic explants of sexually mature animals $[34,35]$, and accelerates the pulsatile GnRH secretion required for sexual maturation in both males and females $[33,36]$. In line with these data, the expression of oxytocin [37] and its receptor [38] increases in the hypothalamus at the time of puberty. Blocking PGE2 synthesis inhibits the increase in the GnRH pulse frequency elicited by oxytocin in hypothalamic explants from prepubertal female rats. The observation that oxytocin receptors are not detected in GnRH neurons but in adjacent astrocytes [33] suggests that, as for EGF-related peptides, the stimulatory effect of oxytocin on $\mathrm{GnRH}$ neurons requires glial mediation through the release of PGE2.
Tanycytes are another source of PGE2 at the level of the median eminence. As in hypothalamic astrocytes, erbB1 ligands activate erbB1/erbB2 heterodimers in tanycytes, resulting in the production of PGE2 [39]. Another mechanism of PGE2 release involves the endothelial cells of the fenestrated capillaries of the portal blood vessels. The activation of endothelial nitric oxide synthase (eNOS) in these cells leads to the production of the gaseous messenger nitric oxide (NO). NO then rapidly diffuses to tanycytes to directly stimulate the enzymatic activity of the cyclooxygenases (COX), which catalyze the synthesis of PGE2 [40, 41].

Once synthesized by glial cells, PGE2 immediately diffuses away to activate specific E-prostanoid receptors (EP) located on GnRH neurons [42-44]. Experiments conducted on median eminence explants and $\mathrm{GnRH}$ producing cells indicate that PGE2 induces the release of GnRH from nerve endings, probably through the activation of EP1 receptors and the downstream mobilization of intracellular calcium stores $[42,45,46]$. PGE2 also acts onto GnRH neurons at the level of the cell body, and appears to be an important regulator of the electrical activity of these neurons. Indeed, PGE2 has recently been shown to exert a powerful excitatory effect on GnRH neurons, involving an EP2-protein kinase A (PKA) signaling pathway that leads to the activation of a nonselective cation conductance. Importantly, the selective inhibition of astrocyte metabolism by fluoroacetate or the impairment of astrocytic PGE2 production due to defective erbB signaling in astrocytes suppresses the spontaneous firing activity of GnRH neurons in brain slices [44]. These results thus identify PGE2 as a novel gliotransmitter, and point to astrocytes as important regulators of $\mathrm{GnRH}$ neuronal excitability. Moreover, astrocytic-derived PGE2 has recently been implicated in the regulation of a local feedback circuit involving GnRH neurons and their GABAergic afferents [47]. However, how the glial modulation of GnRH neuronal electrical activity affects neuropeptide secretion at their nerve endings is still unknown.

Glia-to-GnRH-Neuron Communication via TGF $\beta$ s

A series of in vitro studies have shown that growth factors of the TGF $\beta$ family, which are produced and released from astrocytes [39, 48-51], modulate $\mathrm{GnRH}$ expression, stimulate its release [50-54] and affect steroid metabolism [55] in GnRH-producing cells, which express TGF $\beta$ receptors and their downstream effectors - the Smad proteins $[50,53,56]$. In support of these in vitro studies, TGF $\beta_{1}$, whose levels fluctuate in the hypothalamus across the estrous cycle [57], is selectively detected in astrocytes sur- 


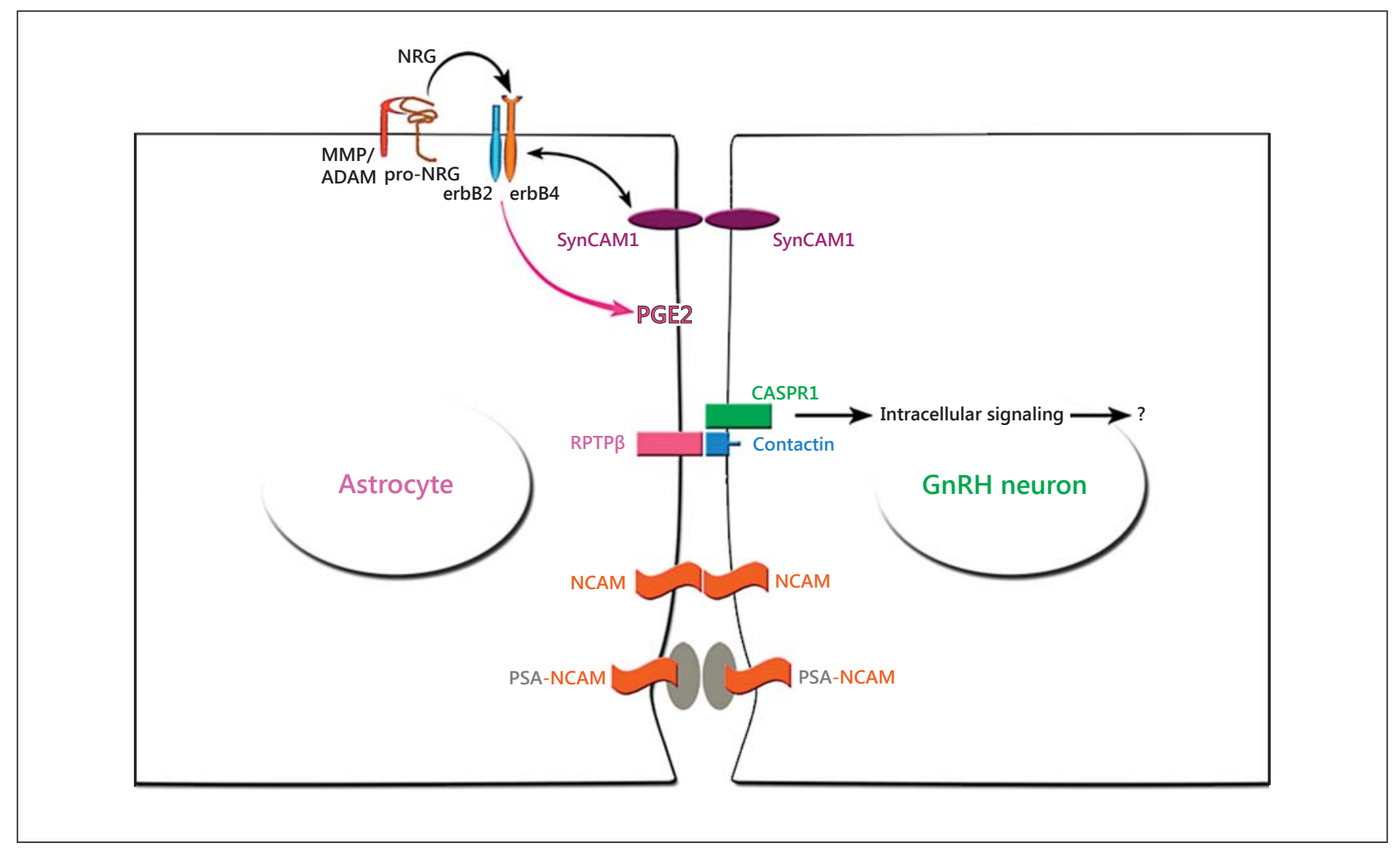

Fig. 4. Juxtacrine interactions between GnRH neurons and glial cells. Synaptic cell adhesion molecule 1 (SynCAM1), which is expressed by astrocytes and GnRH neurons, mediates cell-cell adhesion via homophilic extracellular domain-mediated interactions. The in situ detection of SynCAM protein expression suggests that these interactions occur both at the level of GnRH neuronal perikarya and nerve endings. The SynCAM1 and erbB4 signaling pathways are functionally coupled in hypothalamic astrocytes. The ligand-induced activation of erbB4 receptors promotes the physical interaction of erbB4-SynCAM1 through their intracellular domains and stimulates the adhesive behavior of SynCAM1. SynCAM1 is in turn necessary for neuregulin-dependent erbB4 activation to elicit PGE2 release from astrocytes and GnRH release from nerve terminals $[66,68]$. Hypothalamic astrocytes and GnRH neurons also use the RPTP $\beta /$ contactin/CASPR1 complex for mutual interactions. This ternary complex exhibits both adhesive and signaling properties. The glial transmembrane protein RPTP $\beta$, which possesses intracellular tyrosine phosphatase domains, binds in trans the glycosylphophatidylinositol-anchored neuronal protein contactin. Contactin, which lacks a cytoplasmic domain, interacts

rounding GnRH neurons, while TGF $\beta$ receptors and Smad proteins are expressed in $\mathrm{GnRH}$ perikarya within the rat preoptic region $[58,59]$. Moreover, the incubation of preoptic area explants with $\mathrm{TGF} \beta_{1}$ induces the downregulation of $\mathrm{GnRH}$ expression in individual neurons [58]. In ap- in cis with the transmembrane protein CASPR1 that recruits and activates intracellular signaling pathways thanks to its cytoplasmic proline residues, which serve as binding sites for the $\mathrm{SH} 3$ domains of signaling proteins [113]. The in situ detection of contactin suggests that this ternary complex promotes astrocyte-GnRH-neuron interactions at the level of their nerve terminals (both those reaching the organum vasculosum of the lamina terminalis in the preoptic region and those in the median eminence) but not their perikarya, which seem to lack contactin expression [65]. Both astrocytes and GnRH neurons express PSA-NCAM [62], a plasma membrane-associated cell adhesion glycoprotein. It is worth noting that while RPTP $\beta /$ contactin and SynCAM1 complexes promote cell-cell adhesiveness, the sialylation of NCAM attenuates its adhesive properties, allowing structural remodeling and the movement of cellular elements [61]. The functional consequences of RPTP $\beta /$ contactin and PSA-NCAM interactions between hypothalamic astrocytes and GnRH neurons, in terms of morphological remodeling and/or intracellular signaling, are still to be uncovered. In addition, it is not known at present whether PSA-NCAM, RPTP $\beta$ and SynCAM1 are also expressed at the surface of tanycytes. 
Juxtacrine Interactions between GnRH Neurons and Glial Cells: Role of Adhesion Molecules

\section{PSA-NCAM}

The polysialylated form of the neural cell adhesion molecule (PSA-NCAM), a plasma membrane-associated cell adhesion glycoprotein primarily expressed in regions capable of morphological or physiological plasticity [61], is abundantly expressed in GnRH neurons and astrocytes in adult female rodents (fig. 4), with higher levels in proestrous, when estrogen levels peak, than in diestrous, when estrogen levels are low $[62,63]$. While these observations suggest the possible involvement of PSA-NCAM in the structural neuroglial plasticity modulating $\mathrm{GnRH}$ secretion, as elaborated below, the role of this molecule in the regulation of GnRH neuronal activity and/or secretion and its expression by glial cells remain unclear.

In the search for novel communication molecules involved in female sexual maturation, the group of Ojeda has recently identified cell-cell communication complexes consisting of adhesion/signaling proteins that mediate glial cell adhesiveness to GnRH neurons (fig. 4).

\section{RPTP $\beta /$ Contactin/CASPR1 Complex}

In vitro and in vivo studies performed in nonhuman primates and mice have shown that hypothalamic astrocytes and GnRH neurons use the receptor protein tyrosine phosphatase- $\beta$ (RPTP $\beta$ )/contactin/contactin-associated protein-1 (CASPR1) complex for mutual adhesion. Hypothalamic astrocytes express the transmembrane protein RPTP $\beta$, which interacts with the contactin/ CASPR1 dimer present at the surface of GnRH neurons $[64,65]$. Notably, contactin is expressed in $\mathrm{GnRH}$ nerve terminals but is absent from $\mathrm{GnRH}$ perikarya. While the functional consequences of these adhesive interactions on $\mathrm{GnRH}$ secretion remain unknown, the observation that RPTP $\beta$ mRNA levels increase selectively in the female mouse hypothalamus during the period preceding the onset of puberty, while remaining unchanged in the cerebral cortex [65], raise the possibility that increased interaction between astrocytes and $\mathrm{GnRH}$ axons via the RPTP $\beta /$ contactin/CASPR1 complex may be part of the neuronal-glial communication mechanisms involved in sexual maturation.

\section{SynCAM1}

Astrocytes and GnRH neurons both express synaptic cell adhesion molecule 1 (SynCAM1), which mediates cell-cell adhesion via homophilic extracellular-domainmediated interactions [66]. In nonhuman primates, Syn-
CAM1 expression increases in the hypothalamus at the time of female puberty [67], and the selective disruption of SynCAM1-dependent intracellular signaling in astrocytes delays puberty, disrupts estrous cyclicity and reduces fecundity in mice [68]. Importantly, the SynCAM1 and erbB4 signaling pathways are functionally coupled in hypothalamic astrocytes. The ligand-induced activation of erbB4 receptors promotes the physical interaction of erbB4 and SynCAM1 through their intracellular domains, activates SynCAM1 gene transcription and stimulates its adhesive behavior $[66,68]$. SynCAM1 is in turn necessary for neuregulin-dependent erbB4 activation to elicit PGE2 release from astrocytes and $\mathrm{GnRH}$ release from nerve terminals [68]. It appears, therefore, that erbB4 and SynCAM1 form a signaling complex in hypothalamic astrocytes that is activated at puberty and promotes female reproductive capacity by jointly regulating adhesive and paracrine communication between astrocytes and GnRH neurons.

\section{Plasticity of the Glial Coverage of GnRH Neurons}

Glial cells are known to undergo highly dynamic morphological changes in response to a wide range of stimuli, which ultimately result in the modification of neuronal function [69]. A spectacular example of such morphological plasticity has been described at the level of the median eminence during the ovarian cycle (fig. 5). Ultrastructural studies have revealed that under conditions of low gonadotropin output, such as in diestrus, tanycytes envelop neurosecretory GnRH nerve terminals and prevent them from directly contacting the perivascular space via their end-feet. Intriguingly, this arrangement appears to be specific to $\mathrm{GnRH}$ neurons, and is not as pronounced for the other neuroendocrine systems terminating in the median eminence [70-75]. During the preovulatory surge on the day of proestrus, tanycytes undergo structural remodeling that removes this physical barrier and permits the establishment of direct contact between GnRH nerve endings and basal lamina of the pericapillary space [11, 76], thus favoring the release of $\mathrm{GnRH}$ into the portal blood. Notably, a decrease in membrane apposition between GnRH terminals and glial cells has been noted in older female rats $[13,77]$, raising the possibility that altered structural neuroglial plasticity within the median eminence participates in the mechanisms underlying reduced GnRH output during reproductive aging.

Interestingly, the molecular components involved in the paracrine communication between astroglia and $\mathrm{GnRH}$ neurons are also involved in regulating this morphological plasticity, but through distinct mechanisms. 


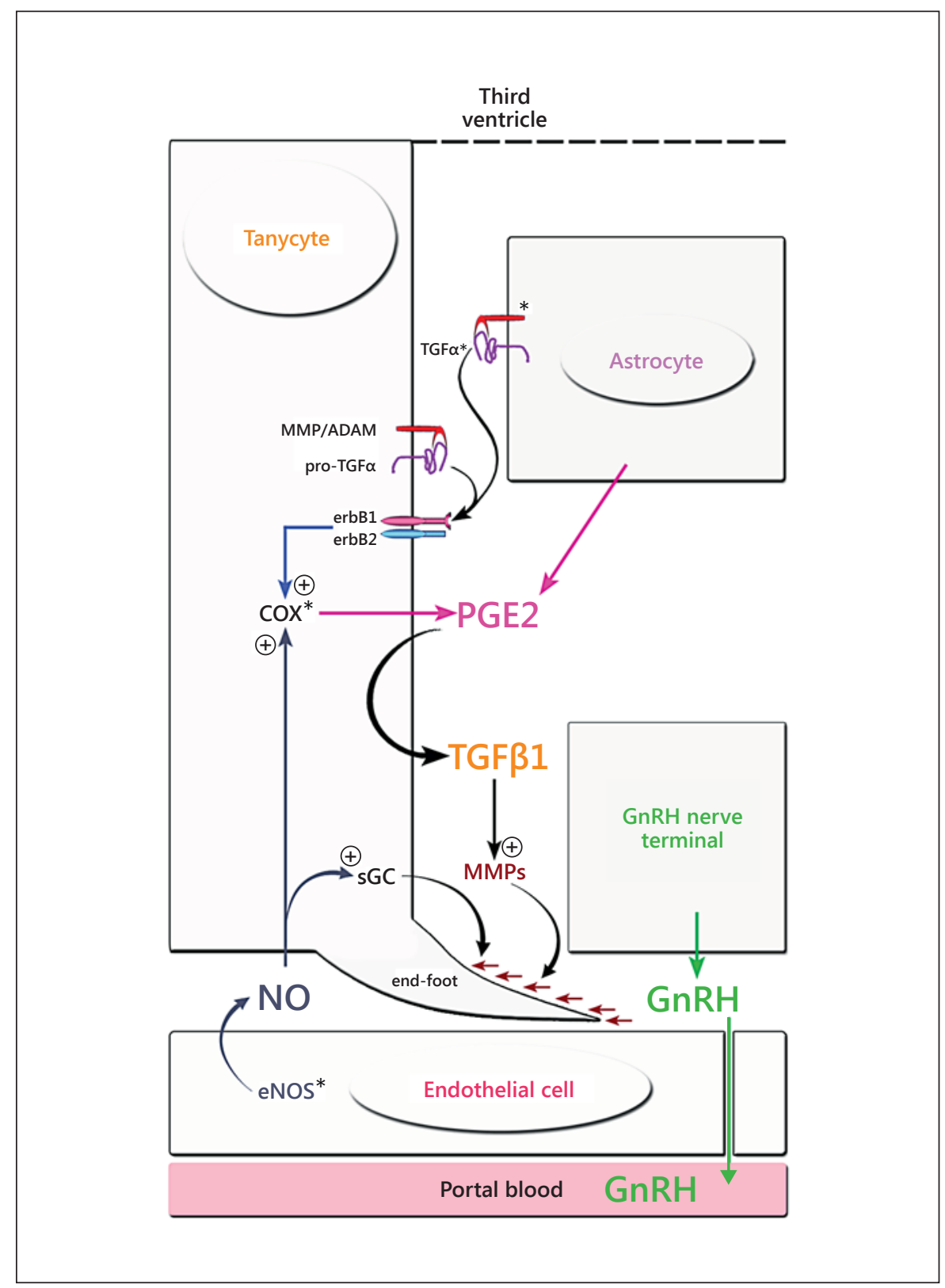

Fig. 5. Morphological plasticity of the glial coverage of GnRH neurons in the median eminence. Under conditions of low gonadotropin output such as in diestrus, tanycytes envelop neurosecretory $\mathrm{GnRH}$ nerve terminals and, through their end-feet, prevent them from directly contacting the perivascular space and releasing $\mathrm{GnRH}$ into the vascular compartment. TGFa, which is produced by tanycytes and astrocytes $[27,39,79]$, activates erbB1/erbB2 heterodimers to stimulate the production of PGE2 and the subsequent PGE2-dependent release of TGF $\beta_{1}$ from tanycytes. Astrocytes also provide a source of PGE2 in response to EGF peptides (fig. 3). Tanycyte-derived TGF $\beta_{1}$ acts in an autocrine manner to induce the retraction of tanycytic processes through the MMP-mediated degradation of extracellular matrix [39]. Endothelial cells also regulate the morphological plasticity of tanycytes via the release of NO, which diffuses to tanycytes to stimulate the enzymatic activity of COX and of the NO-sensitive soluble guanylyl cyclase (sGC) [40]. Notably, the mechanism by which the activation of sGC promotes actin cytoskeleton remodeling in tanycytes remains unknown. The retraction of tanycytic end-feet enables GnRH nerve endings to make direct contact with the pericapillary space (i.e., the space delineated by the parenchymatous basal lamina on one side and by the endothelial basal lamina on the other side; not shown). The released GnRH then enters the portal blood via the fenestrations of endothelial cells. Asterisks indicate the molecular components shown to be positively regulated by gonadal steroids in primary cultures of astrocytes, tanycytes and endothelial cells (see main text for details). 
Indeed, the EGF and TGF $\beta$ signaling systems converge in tanycytes to regulate their structural remodeling. Tanycytes express both erbB and TGF $\beta$ receptors, as well as their respective ligands $[20,24,27,39,58,59,78]$. TGFa, which is produced by tanycytes and astrocytes [27, 39, 79 ], activates erbB1/erbB2 heterodimers to stimulate the production of PGE2 and the subsequent release of TGF $\beta_{1}$ from primary tanycyte cultures. Notably, this stimulatory mechanism is specific to tanycytes because, while they produce both PGE2 and TGF $\beta_{1}$, hypothalamic astrocytes do not respond to TGFa by further increasing the release of TGF $\beta_{1}$. Tanycyte-derived TGF $\beta_{1}$ acts in an autocrine manner to induce the retraction of tanycytic processes through the metalloproteinase-mediated degradation of the extracellular matrix [39]. The observation that hypothalamic TGFa expression increases before that of TGF $\beta_{1}$ during the period encompassing the preovulatory surge of gonadotropins [27] suggests that the sequence of events identified in vitro $[80,39]$ may also exist in vivo.

The morphological plasticity of tanycytes is also regulated by endothelial signals. In vitro studies using purified cultures of tanycytes and endothelial cells of the median eminence show that endothelial cells promote rapid actin cytoskeleton remodeling in tanycytes through the release of NO $[40,41]$. NO exerts its effects on tanycytes by stimulating the enzymatic activity of both the NO-sensitive guanylyl cyclase and the COX enzymes [40], which produce cGMP [81, 82] and prostaglandin [83], respectively. In agreement with a physiological role for endothelial NO in regulating $\mathrm{GnRH}$ secretion via the modulation of tanycytic plasticity, the activation of endogenous NO secretion in median eminence explants promotes the establishment of direct junctions between $\mathrm{GnRH}$ nerve terminals and the vascular compartment, with very few tanycytic processes remaining around those $\mathrm{GnRH}$ nerve endings that have direct access to the pericapillary space [40]. Moreover, the targeted inhibition of NO production in the median eminence of adult female rats disrupts estrous cyclicity, with a reduction in the percentage of days in proestrus and estrus, when GnRH nerve endings form direct neurovascular junctions with the pituitary portal blood system [40].

A few studies suggest that the remodeling of the glial coverage of GnRH neurons may also occur at the level of their cell bodies, in response to varying levels of gonadal steroids. Morphometric changes in the surface area of astrocytes apposed to $\mathrm{GnRH}$ cell bodies have been described across natural [84] and artificial [85] estrous cycles in female rats. Notably, these studies rely on immunolabeling for the cytoskeletal glial fibrillary acidic protein (GFAP), which does not give a true representation of the highly complex, 'bushy' structure of astrocytes (fig. 1a, inset). An ultrastructural study performed in female rhesus monkeys has shown that ovariectomy induces an increase in the apposition of glial processes to $\mathrm{GnRH}$ perikarya, associated with a decrease in their synaptic inputs, while steroid replacement reduces the glial ensheathment of GnRH neurons and increases their innervation [6]. Further studies are needed to determine whether the remodeling of the astrocytic coverage of GnRH neuronal cell bodies affects their electrical activity and, ultimately, their neurosecretory output.

\section{Glial Cells: Sensors and Effectors of Sex Steroid Actions in the Neuroendocrine Brain}

Most of the above-described mechanisms for the glial control of GnRH neurons have been shown to be under the regulatory influence of gonadal steroids, whose circulating levels rise dramatically at the onset of the preovulatory GnRH/LH surge [86]. The in vivo manipulation of sex steroid levels demonstrates their stimulatory effect on the hypothalamic expression of TGFa [27], erbB2 and erbB4 [20], oxytocin [37,87,88], the oxytocin receptor $[89,90], \mathrm{TGF} \beta_{1}$ [57] and PSA-NCAM [62]. At least some of these effects may be mediated by a direct action of gonadal steroids on astrocytes, which express steroid receptors [91], since the in vitro treatment of hypothalamic astrocytes with estradiol increases the expression of TGFa [92] and the enzymatic activity of TACE [26]. Estradiol further enhances the efficacy of the TGFa/erbB1/PGE2 signaling system by stimulating the expression of prostaglandin receptors in $\mathrm{GnRH}$-producing cells through the secretion of glial signals [42]. In addition, hypothalamic astrocytes respond to progestogens and estradiol by increased TGF $\beta_{1}$ gene expression [93] and release [50, 54], respectively. Tanycytes also express estrogen receptors in situ and in vitro $[41,94]$. Estradiol may regulate tanycytic morphological plasticity by controlling eNOS and COX protein expression in median eminence endothelial cells and tanycytes, respectively, and thus the dialogue set in motion between these non-neuronal cell types [41]. However, astroglia may not just be passive sensors of peripheral steroid hormones. Work from the group of Micevych (reviewed in [95]) suggests that hypothalamic astrocytes play a critical role in regulating positive feedback by estrogen. Indeed, they have shown that rising estradiol levels initiate a membrane-associated estradiol signaling cascade involving the transactivation of metabotropic 
glutamate receptor type 1a (mGluR1a) in hypothalamic astrocytes, which ultimately leads to the synthesis of progesterone, critical for initiating the LH surge. Moreover, primate studies have identified rapid excitatory effects of estradiol on GnRH neuronal activity and suggest that estradiol locally synthesized in the hypothalamus may play a significant role in the control of the preovulatory surge and/or pulsatile release of GnRH [96]. Since data from rodents and humans suggest that astrocytes are a source of estrogens in the brain $[97,98]$, these observations raise the possibility that astrocytes could contribute to the regulation of GnRH neuronal activity and secretion via the local synthesis of neuroestrogens.

\section{Do Glial Cells Regulate the GnRH System in the Human Brain?}

While most of the data concerning the glial regulation of GnRH neurons have been obtained from rodents and nonhuman primates, studies conducted in humans suggest that at least some of these mechanisms are also at work in our species. A neuroanatomical study has shown that GnRH neurons in the adult human hypothalamus intimately interact with glial cells both at the level of their cell bodies and their nerve terminals, as they do in rodents [12]. Interestingly, the observation that some hypothalamic hamartomas, non-neoplastic hypothalamic tumors associated with precocious puberty, are rich in astrocytes expressing TGFa and its receptor erbB1 [99], associated with the demonstration that human hypothalamic astrocytes express a functional erbB signaling system [79], raise the possibility that the activation of erbB receptors in human astrocytes may set in motion glia-to-neuron signaling capable of stimulating $\mathrm{GnRH}$ neurons.

Metabolic magnetic resonance imaging studies performed on young women have revealed sex-steroid-driven plasticity in the hypothalamus in vivo [100]. During the pill-free period, when the hypothalamus is active and normal early-follicular-phase pulsatile LH release occurs, there is higher water molecule diffusion and lower levels of choline [100], a metabolite enriched in astrocytes [102, 103], than in the pill-supplemented period, when the hypothalamic-pituitary-gonadal axis is fully inhibited [101]. Although the underlying mechanisms remain to be determined, the increase in water diffusion and reduction in choline levels may reflect a decrease in the tortuosity of the extracellular space due to diminished astroglial cell size, as shown for other neuroendocrine systems [104].
Importantly, such modifications are not observed in the thalamus, a brain structure that is unrelated to reproductive control. These data raise the possibility that transient changes in glial microstructure participate in the control of GnRH secretion in humans.

Notably, even though some of the mechanisms used by rodent astrocytes to control $\mathrm{GnRH}$ secretion appear to be conserved in humans, divergences certainly exist. Importantly, clear differences have been described in the neural and hormonal control of the preovulatory GnRH/LH surge between rodents and higher primates $[96,105]$. In addition, astrocytes in the human cerebral cortex exhibit increased size, structural complexity, diversity and speed of $\mathrm{Ca}^{2+}$ wave propagation than their rodent counterparts [106]. At the molecular level, even though they express the same set of erbB receptors (i.e. erbB1, erbB2 and erbB4), human hypothalamic astrocytes appear to respond to the neuregulins through the activation of erbB4/ erbB4 homodimers [79], while rodent astrocytes recruit erbB4/erbB2 heterodimers [20]. Although the functional consequences of these signaling differences remain to be determined, these observations suggest that human hypothalamic astrocytes exhibit unique features that need to be explored in future studies.

\section{Concluding Remarks}

From the body of data reviewed here, it now appears that glial cells, in addition to transsynaptic neuronal control, are critical regulators of $\mathrm{GnRH}$ neuronal activity and secretion. Glial cells are an abundant source of cellular and molecular strategies to control the electrical and neurosecretory activity of GnRH neurons, both at the level of their cell bodies and at the level of their nerve endings. In vitro studies have provided significant insights into some of the molecular determinants of gliato-GnRH-neuron communication systems, and the in vivo deregulation of these signals, some of them targeting astrocytes, have demonstrated their relevance to the central control of reproduction. Nevertheless, the development of additional transgenic animals in which the molecules involved in glia-to-GnRH-neuron communication can be specifically targeted both in space (i.e. in astrocytes and/or tanycytes) and time (at the onset of puberty or at critical periods of the estrous cycle), will enable us to refine our understanding of the role of glia in the control of $\mathrm{GnRH}$ function. In addition, a still-mysterious aspect of $\mathrm{GnRH}$ system physiology is the mechanism by which these neurons, which are scattered within 
a vast hypothalamic area, synchronize to generate the pulsatile release of neuropeptide. Given the network organization of astrocytes, which provides them with the potential ability to coordinate distant neuronal units via the multidirectional spread of signaling molecules [107], glial cells may also contribute to the mechanisms underlying the control of the GnRH system at a network level. Future studies addressing these issues promise to generate exciting new data.

\section{Acknowledgements}

This research was supported by the Institut National de la Santé et de la Recherche Médicale (INSERM, France) Grant U837, the Fondation pour la Recherche Médicale (Equipe FRM 2005), l'Agence Nationale de la Recherche (ANR) grant ANR-09BLAN-0267, the Université Lille 2 and the imaging and animal facilities of IFR114. We thank Danièle Mazur for expert technical assistance and Delphine Taillieu and Julien Devassine for the maintenance of animals.

\section{References}

1 Ojeda SR, Skinner MK: Puberty in the rat; in Neill JD (ed): Knobil and Neill's Physiology of Reproduction. San Diego, Academic Press, 2006, pp 2026-2126.

- 2 Ojeda SR, Roth C, Mungenast A, Heger S, Mastronardi C, Parent AS, Lomniczi A, Jung $\mathrm{H}$ : Neuroendocrine mechanisms controlling female puberty: new approaches, new concepts. Int J Androl 2006;29:256-263.

-3 Christian CA, Moenter SM: The neurobiology of preovulatory and estradiol-induced gonadotropin-releasing hormone surges. Endocr Rev 2010;31:544-577.

4 Herbison AE: Physiology of the gonadotropin-releasing hormone neuronal network; in Neill JD (ed): Knobil and Neill's Physiology of Reproduction. San Diego, Academic Press, 2006, pp 1415-1482.

5 Kozlowski GP, Coates PW: Ependymoneuronal specializations between LHRH fibers and cells of the cerebroventricular system. Cell Tissue Res 1985;242:301-311.

6 Witkin JW, Ferin M, Popilskis SJ, Silverman AJ: Effects of gonadal steroids on the ultrastructure of GnRH neurons in the rhesus monkey: synaptic input and glial apposition. Endocrinology 1991;129:1083-1092.

7 Romero MT, Silverman AJ, Wise PM, Witkin JW: Ultrastructural changes in gonadotropinreleasing hormone neurons as a function of age and ovariectomy in rats. Neuroscience 1994;58:217-225.

8 King JC, Letourneau RJ: Luteinizing hormone-releasing hormone terminals in the median eminence of rats undergo dramatic changes after gonadectomy, as revealed by electron microscopic image analysis. Endocrinology 1994;134:1340-1351.

-9 Perera AD, Plant TM: Ultrastructural studies of neuronal correlates of the pubertal reaugmentation of hypothalamic gonadotropin-releasing hormone $(\mathrm{GnRH})$ release in the rhesus monkey (Macaca mulatta). J Comp Neurol 1997;385:71-82.

10 Durrant AR, Plant TM: A study of the gonadotropin releasing hormone neuronal network in the median eminence of the rhesus monkey (Macaca mulatta) using a post-embedding immunolabelling procedure. J Neuroendocrinol 1999;11:813-821.

11 Prevot V, Croix D, Bouret S, Dutoit S, Tramu G, Stefano GB, Beauvillain JC: Definitive evidence for the existence of morphological plasticity in the external zone of the median eminence during the rat estrous cycle: implication of neuro-glio-endothelial interactions in gonadotropin-releasing hormone release. Neuroscience 1999;94:809-819.

12 Baroncini M, Allet C, Leroy D, Beauvillain JC, Francke JP, Prevot V: Morphological evidence for direct interaction between gonadotrophin-releasing hormone neurones and astroglial cells in the human hypothalamus. J Neuroendocrinol 2007;19:691-702.

13 Yin W, Mendenhall JM, Monita M, Gore AC: Three-dimensional properties of GnRH neuroterminals in the median eminence of young and old rats. J Comp Neurol 2009;517:284295.

14 Richter TA, Keen KL, Terasawa E: Synchronization of $\mathrm{Ca}(2+)$ oscillations among primate LHRH neurons and nonneuronal cells in vitro. J Neurophysiol 2002;88:1559-1567.

15 Geller S, Kolasa E, Tillet Y, Duittoz A, Vaudin $\mathrm{P}$ : Olfactory ensheathing cells form the microenvironment of migrating GnRH-1 neurons during mouse development. Glia 2013; 61:550-566.

16 Garcia-Segura LM, Lorenz B, DonCarlos LL: The role of glia in the hypothalamus: implications for gonadal steroid feedback and reproductive neuroendocrine output. Reproduction 2008;135:419-429.

17 Clasadonte J, Sharif A, Baroncini M, Prevot V: Gliotransmission by prostaglandin $\mathrm{E}(2)$ : a prerequisite for GnRH neuronal function? Front Endocrinol (Lausanne) 2011;2:91.

18 Riese DJ 2nd, Stern DF: Specificity within the EGF family/ErbB receptor family signaling network. Bioessays 1998;20:41-48.

$\checkmark 19$ Dziedzic B, Prevot V, Lomniczi A, Jung H, Cornea A, Ojeda SR: Neuron-to-glia signaling mediated by excitatory amino acid receptors regulates ErbB receptor function in astroglial cells of the neuroendocrine brain. J Neurosci 2003;23:915-926.
20 Ma YJ, Hill DF, Creswick KE, Costa ME, Cornea A, Lioubin MN, Plowman GD, Ojeda SR: Neuregulins signaling via a glial erbB-2erbB-4 receptor complex contribute to the neuroendocrine control of mammalian sexual development. J Neurosci 1999;19:99139927.

21 Prevot V, Rio C, Cho GJ, Lomniczi A, Heger S, Neville CM, Rosenthal NA, Ojeda SR, Corfas G: Normal female sexual development requires neuregulin-erbB receptor signaling in hypothalamic astrocytes. J Neurosci 2003;23: 230-239.

22 Ma YJ, Berg-von der Emde K, Rage F, Wetsel WC, Ojeda SR: Hypothalamic astrocytes respond to transforming growth factor-alpha with the secretion of neuroactive substances that stimulate the release of luteinizing hormone-releasing hormone. Endocrinology 1997;138:19-25.

23 Prevot V, Lomniczi A, Corfas G, Ojeda SR: erbB-1 and erbB-4 receptors act in concert to facilitate female sexual development and mature reproductive function. Endocrinology 2005;146:1465-1472.

24 Ma YJ, Hill DF, Junier MP, Costa ME, Felder SE, Ojeda SR: Expression of epidermal growth factor receptor changes in the hypothalamus during the onset of female puberty. Mol Cell Neurosci 1994;5:246-262.

25 Voigt P, Ma YJ, Gonzalez D, Fahrenbach WH, Wetsel WC, Berg-von der Emde K, Hill DF, Taylor KG, Costa ME, Seidah NG, Ojeda SR: Neural and glial-mediated effects of growth factors acting via tyrosine kinase receptors on luteinizing hormone-releasing hormone neurons. Endocrinology 1996;137:2593-2605.

26 Lomniczi A, Cornea A, Costa ME, Ojeda SR: Hypothalamic tumor necrosis factor-alpha converting enzyme mediates excitatory amino acid-dependent neuron-to-glia signaling in the neuroendocrine brain. J Neurosci 2006; 26:51-62.

27 Ma YJ, Junier MP, Costa ME, Ojeda SR: Transforming growth factor-alpha gene expression in the hypothalamus is developmentally regulated and linked to sexual maturation. Neuron 1992;9:657-670. 
-28 Ma YJ, Costa ME, Ojeda SR: Developmental expression of the genes encoding transforming growth factor alpha and its receptor in the hypothalamus of female rhesus macaques. Neuroendocrinology 1994;60:346-359.

-29 Apostolakis EM, Garai J, Lohmann JE, Clark JH, O’Malley BW: Epidermal growth factor activates reproductive behavior independent of ovarian steroids in female rodents. Mol Endocrinol 2000;14:1086-1098.

- 30 Junier MP, Ma YJ, Costa ME, Hoffman G, Hill DF, Ojeda SR: Transforming growth factor alpha contributes to the mechanism by which hypothalamic injury induces precocious puberty. Proc Natl Acad Sci USA 1991;88:97439747.

-31 Ma YJ, Dissen GA, Merlino G, Coquelin A, Ojeda SR: Overexpression of a human transforming growth factor-alpha (TGF-alpha) transgene reveals a dual antagonistic role of TGF alpha in female sexual development. Endocrinology 1994;135:1392-1400.

- 32 Rage F, Hill DF, Sena-Esteves M, Breakefield XO, Coffey RJ, Costa ME, McCann SM, Ojeda SR: Targeting transforming growth factor alpha expression to discrete loci of the neuroendocrine brain induces female sexual precocity. Proc Natl Acad Sci USA 1997;94:27352740.

-33 Parent AS, Rasier G, Matagne V, Lomniczi A, Lebrethon MC, Gerard A, Ojeda SR, Bourguignon JP: Oxytocin facilitates female sexual maturation through a glia-to-neuron signaling pathway. Endocrinology 2008; 149:13581365.

- 34 Rettori V, Canteros G, Renoso R, Gimeno M, McCann SM: Oxytocin stimulates the release of luteinizing hormone-releasing hormone from medial basal hypothalamic explants by releasing nitric oxide. Proc Natl Acad Sci USA 1997;94:2741-2744.

- 35 Selvage D, Johnston CA: Central stimulatory influence of oxytocin on preovulatory gonadotropin-releasing hormone requires more than the median eminence. Neuroendocrinology 2001;74:129-134.

- 36 Parent AS, Lebrethon MC, Gerard A, Bourguignon JP: Factors accounting for perinatal occurrence of pulsatile gonadotropin-releasing hormone secretion in vitro in rats. Biol Reprod 2005;72:143-149.

-37 Miller FD, Ozimek G, Milner RJ, Bloom FE: Regulation of neuronal oxytocin mRNA by ovarian steroids in the mature and developing hypothalamus. Proc Natl Acad Sci USA 1989; 86:2468-2472.

- 38 Tribollet E, Charpak S, Schmidt A, DuboisDauphin M, Dreifuss JJ: Appearance and transient expression of oxytocin receptors in fetal, infant, and peripubertal rat brain studied by autoradiography and electrophysiology. J Neurosci 1989;9:1764-1773.

- 39 Prevot V, Cornea A, Mungenast A, Smiley G, Ojeda SR: Activation of erbB-1 signaling in tanycytes of the median eminence stimulates transforming growth factor betal release via prostaglandin $\mathrm{E}_{2}$ production and induces cell plasticity. J Neurosci 2003;23: 10622-10632.

40 De Seranno S, Estrella C, Loyens A, Cornea A, Ojeda SR, Beauvillain JC, Prevot V: Vascular endothelial cells promote acute plasticity in ependymoglial cells of the neuroendocrine brain. J Neurosci 2004;24:10353-10363.

41 de Seranno S, d'Anglemont de Tassigny X, Estrella C, Loyens A, Kasparov S, Leroy D, Ojeda SR, Beauvillain JC, Prevot V: Role of estradiol in the dynamic control of tanycyte plasticity mediated by vascular endothelial cells in the median eminence. Endocrinology 2010; 151:1760-1772.

42 Rage F, Lee BJ, Ma YJ, Ojeda SR: Estradiol enhances prostaglandin $\mathrm{E}_{2}$ receptor gene expression in luteinizing hormone-releasing hormone (LHRH) neurons and facilitates the LHRH response to PGE2 by activating a gliato-neuron signaling pathway. J Neurosci 1997;17:9145-9156.

-43 Jasoni CL, Todman MG, Han SK, Herbison AE: Expression of mRNAs encoding receptors that mediate stress signals in gonadotropin-releasing hormone neurons of the mouse. Neuroendocrinology 2005;82:320-328.

44 Clasadonte J, Poulain P, Hanchate NK, Corfas G, Ojeda SR, Prevot V: Prostaglandin $E_{2}$ release from astrocytes triggers gonadotropinreleasing hormone $(\mathrm{GnRH})$ neuron firing via EP2 receptor activation. Proc Natl Acad Sci USA 2011;108:16104-16109.

-45 Ojeda SR, Negro-Vilar A: Prostaglandin $E_{2}-$ induced luteinizing hormone-releasing hormone release involves mobilization of intracellular $\mathrm{Ca}^{2+}$. Endocrinology 1985;116:17631770.

46 Ojeda SR, Urbanski HF, Katz KH, Costa ME: Prostaglandin $\mathrm{E}_{2}$ releases luteinizing hormone-releasing hormone from the female juvenile hypothalamus through a $\mathrm{Ca}^{2+}$-dependent, calmodulin-independent mechanism. Brain Res 1988;441:339-351.

47 Glanowska KM, Moenter SM: Endocannabinoids and prostaglandins both contribute to GnRH neuron-GABAergic afferent local feedback circuits. J Neurophysiol 2011;106: 3073-3081.

- 48 Constam DB, Philipp J, Malipiero UV, ten Dijke P, Schachner M, Fontana A: Differential expression of transforming growth factor-beta 1 , -beta 2 , and -beta 3 by glioblastoma cells, astrocytes, and microglia. J Immunol 1992; 148:1404-1410.

49 Saad B, Constam DB, Ortmann R, Moos M, Fontana A, Schachner M: Astrocyte-derived TGF-beta 2 and NGF differentially regulate neural recognition molecule expression by cultured astrocytes. J Cell Biol 1991;115:473484.

50 Buchanan CD, Mahesh VB, Brann DW: Estrogen-astrocyte-luteinizing hormone-releasing hormone signaling: a role for transforming growth factor-beta(1). Biol Reprod 2000;62:1710-1721.

51 Melcangi RC, Galbiati M, Messi E, Piva F, Martini L, Motta M: Type 1 astrocytes influ- ence luteinizing hormone-releasing hormone release from the hypothalamic cell line GT11. Is transforming growth factor-beta the principle involved? Endocrinology 1995;136: 679-686.

52 Galbiati M, Zanisi M, Messi E, Cavarretta I, Martini L, Melcangi RC: Transforming growth factor-beta and astrocytic conditioned medium influence luteinizing hormone-releasing hormone gene expression in the hypothalamic cell line GT1. Endocrinology 1996;137:5605-5609.

53 Messi E, Galbiati M, Magnaghi V, Zucchi I, Martini L, Melcangi RC: Transforming growth factor beta2 is able to modify mRNA levels and release of luteinizing hormone-releasing hormone in a immortalized hypothalamic cell line (GT1-1). Neurosci Lett 1999; 270:165-168.

54 Zwain IH, Arroyo A, Amato P, Yen SS: A role for hypothalamic astrocytes in dehydroepiandrosterone and estradiol regulation of gonadotropin-releasing hormone $(\mathrm{GnRH})$ release by $\mathrm{GnRH}$ neurons. Neuroendocrinology 2002;75:375-383.

55 Cavarretta I, Magnaghi V, Ferraboschi P, Martini L, Melcangi RC: Interactions between type 1 astrocytes and LHRH-secreting neurons (GT1-1 cells): modification of steroid metabolism and possible role of TGFbeta1. J Steroid Biochem Mol Biol 1999;71:41-47.

56 Galbiati M, Saredi S, Romano N, Martini L, Motta M, Melcangi RC: Smad proteins are targets of transforming growth factor betal in immortalised gonadotrophin-releasing hormone releasing neurones. J Neuroendocrinol 2005; 17:753-760.

57 Galbiati M, Magnaghi V, Martini L, Melcangi RC: Hypothalamic transforming growth factor betal and basic fibroblast growth factor mRNA expression is modified during the rat oestrous cycle. J Neuroendocrinol 2001;13: 483-489.

58 Bouret S, De Seranno S, Beauvillain JC, Prevot $\mathrm{V}$ : Transforming growth factor beta 1 may directly influence gonadotropin-releasing hormone gene expression in the rat hypothalamus. Endocrinology 2004;145:1794-1801.

-59 Prevot V, Bouret S, Croix D, Takumi T, Jennes L, Mitchell V, Beauvillain JC: Evidence that members of the TGFbeta superfamily play a role in regulation of the GnRH neuroendocrine axis: expression of a type I serinethreonine kinase receptor for TGFbeta and activin in GnRH neurones and hypothalamic areas of the female rat. J Neuroendocrinol 2000;12:665-670.

60 Ojeda SR, Urbanski HF, Costa ME, Hill DF, Moholt-Siebert M: Involvement of transforming growth factor alpha in the release of luteinizing hormone-releasing hormone from the developing female hypothalamus. Proc Natl Acad Sci USA 1990;87:9698-9702.

61 Rutishauser U, Landmesser L: Polysialic acid in the vertebrate nervous system: a promoter of plasticity in cell-cell interactions. Trends Neurosci 1996;19:422-427. 
62 Parkash J, Kaur G: Neuronal-glial plasticity in gonadotropin-releasing hormone release in adult female rats: role of the polysialylated form of the neural cell adhesion molecule. J Endocrinol 2005;186:397-409.

63 Tan O, Fadiel A, Chang A, Demir N, Jeffrey R, Horvath T, Garcia-Segura LM, Naftolin F: Estrogens regulate posttranslational modification of neural cell adhesion molecule during the estrogen-induced gonadotropin surge. Endocrinology 2009; 150: 2783-2790.

64 Mungenast AE, Ojeda SR: Expression of three gene families encoding cell-cell communication molecules in the prepubertal nonhuman primate hypothalamus. J Neuroendocrinol 2005; 17:208-219.

- 65 Parent AS, Mungenast AE, Lomniczi A, Sandau US, Peles E, Bosch MA, Ronnekleiv OK, Ojeda SR: A contactin-receptor-like protein tyrosine phosphatase beta complex mediates adhesive communication between astroglial cells and gonadotrophin-releasing hormone neurones. J Neuroendocrinol 2007; 19 : 847-859.

-66 Sandau US, Mungenast AE, McCarthy J, Biederer T, Corfas G, Ojeda SR: The synaptic cell adhesion molecule, SynCAM1, mediates astrocyte-to-astrocyte and astrocyte-toGnRH neuron adhesiveness in the mouse hypothalamus. Endocrinology 2011;152: 2353-2363.

-67 Roth CL, Mastronardi C, Lomniczi A, Wright $\mathrm{H}$, Cabrera R, Mungenast AE, Heger S, Jung H, Dubay C, Ojeda SR: Expression of a tumorrelated gene network increases in the mammalian hypothalamus at the time of female puberty. Endocrinology 2007;148:5147-5161.

-68 Sandau US, Mungenast AE, Alderman Z, Sardi SP, Fogel AI, Taylor B, Parent AS, Biederer T, Corfas G, Ojeda SR: SynCAM1, a synaptic adhesion molecule, is expressed in astrocytes and contributes to erbB4 receptor-mediated control of female sexual development. Endocrinology 2011;152:2364-2376.

69 Theodosis DT, Poulain DA, Oliet SH: Activity-dependent structural and functional plasticity of astrocyte-neuron interactions. Physiol Rev 2008;88:983-1008.

70 Ugrumov M, Hisano S, Daikoku S: Topographic relations between tyrosine hydroxylase- and luteinizing hormone-releasing hormone-immunoreactive fibers in the median eminence of adult rats. Neurosci Lett 1989; 102:159-164.

-71 Liposits Z, Gorcs T, Setalo G, Lengvari I, Flerko B, Vigh S, Schally AV: Ultrastructural characteristics of immunolabelled, corticotropin releasing factor (CRF)-synthesizing neurons in the rat brain. Cell Tissue Res 1983; 229:191-196.

72 Beauvillain JC, Tramu G, Garaud JC: Coexistence of substances related to enkephalin and somatostatin in granules of the guinea-pig median eminence: demonstration by use of colloidal gold immunocytochemical methods. Brain Res 1984;301:389-393.
73 Jew JY, Leranth C, Arimura A, Palkovits M: Preoptic LH-RH and somatostatin in the rat median eminence. An experimental light and electron microscopic immunocytochemical study. Neuroendocrinology 1984;38:169-175.

74 Hisano S, Ishizuka H, Nishiyama T, Tsuruo Y, Katoh S, Daikoku S: Immunoelectron microscopic observations of hypothalamic TRHcontaining neurons in rats. Exp Brain Res 1986;63:495-504.

75 Ibata Y, Okamura H, Makino S, Kawakami F, Morimoto N, Chihara K: Light and electron microscopic immunocytochemistry of GRFlike immunoreactive neurons and terminals in the rat hypothalamic arcuate nucleus and median eminence. Brain Res 1986;370:136143.

76 Prevot V, Dutoit S, Croix D, Tramu G, Beauvillain JC: Semi-quantitative ultrastructural analysis of the localization and neuropeptide content of gonadotropin releasing hormone nerve terminals in the median eminence throughout the estrous cycle of the rat. Neuroscience 1998;84:177-191.

77 Yin W, Wu D, Noel ML, Gore AC: Gonadotropin-releasing hormone neuroterminals and their microenvironment in the median eminence: effects of aging and estradiol treatment. Endocrinology 2009;150:5498-5508.

78 Steiner H, Blum M, Kitai ST, Fedi P: Differential expression of ErbB3 and ErbB4 neuregulin receptors in dopamine neurons and forebrain areas of the adult rat. Exp Neurol 1999; 159:494-503.

79 Sharif A, Duhem-Tonnelle V, Allet C, Baroncini M, Loyens A, Kerr-Conte J, Collier F, Blond S, Ojeda SR, Junier MP, Prevot V: Differential erbB signaling in astrocytes from the cerebral cortex and the hypothalamus of the human brain. Glia 2009;57:362-379.

80 Galbiati M, Martini L, Melcangi RC: Oestrogens, via transforming growth factor alpha, modulate basic fibroblast growth factor synthesis in hypothalamic astrocytes: in vitro observations. J Neuroendocrinol 2002;14:829835.

81 Koesling D, Friebe A: Soluble guanylyl cyclase: structure and regulation. Rev Physiol Biochem Pharmacol 1999;135:41-65.

82 Bredt DS: Nitric oxide signaling specificity the heart of the problem. J Cell Sci 2003;116: 9-15.

83 Salvemini D, Misko TP, Masferrer JL, Seibert K, Currie MG, Needleman P: Nitric oxide activates cyclooxygenase enzymes. Proc Natl Acad Sci USA 1993;90:7240-7244.

84 Cashion AB, Smith MJ, Wise PM: The morphometry of astrocytes in the rostral preoptic area exhibits a diurnal rhythm on proestrus: relationship to the luteinizing hormone surge and effects of age. Endocrinology 2003;144: 274-280.

85 Gerhold LM, Wise PM: Vasoactive intestinal polypeptide regulates dynamic changes in astrocyte morphometry: impact on gonadotropin-releasing hormone neurons. Endocrinology 2006;147:2197-2202.
86 Smith MS, Freeman ME, Neill JD: The control of progesterone secretion during the estrous cycle and early pseudopregnancy in the rat: prolactin, gonadotropin and steroid levels associated with rescue of the corpus luteum of pseudopregnancy. Endocrinology 1975;96: 219-226.

87 Chibbar R, Toma JG, Mitchell BF, Miller FD Regulation of neural oxytocin gene expression by gonadal steroids in pubertal rats. Mol Endocrinol 1990;4:2030-2038.

88 Nomura M, McKenna E, Korach KS, Pfaff DW, Ogawa S: Estrogen receptor-beta regulates transcript levels for oxytocin and arginine vasopressin in the hypothalamic paraventricular nucleus of male mice. Brain Res Mol Brain Res 2002;109:84-94.

89 Johnson AE, Ball GF, Coirini H, Harbaugh CR, McEwen BS, Insel TR: Time course of the estradiol-dependent induction of oxytocin receptor binding in the ventromedial hypothalamic nucleus of the rat. Endocrinology 1989:125:1414-1419.

90 de Kloet ER, Voorhuis DA, Boschma Y, Elands $\mathrm{J}$ : Estradiol modulates density of putative 'oxytocin receptors' in discrete rat brain regions. Neuroendocrinology 1986;44:415-421.

91 Melcangi RC, Magnaghi V, Galbiati M, Martini L: Glial cells: a target for steroid hormones. Prog Brain Res 2001;132:31-40.

92 Ma YJ, Berg-von der Emde K, Moholt-Siebert M, Hill DF, Ojeda SR: Region-specific regulation of transforming growth factor alpha (TGF alpha) gene expression in astrocytes of the neuroendocrine brain. J Neurosci 1994; 14:5644-5651.

93 Melcangi RC, Cavarretta I, Magnaghi V, Martini L, Galbiati M: Interactions between growth factors and steroids in the control of LHRH-secreting neurons. Brain Res Brain Res Rev 2001;37:223-234

94 Langub MC Jr, Watson RE Jr: Estrogen receptor-immunoreactive glia, endothelia, and ependyma in guinea pig preoptic area and median eminence: electron microscopy. Endocrinology 1992;130:364-372.

95 Kuo J, Micevych P: Neurosteroids, trigger of the LH surge. J Steroid Biochem Mol Biol 2012;131:57-65.

-96 Terasawa E, Kenealy BP: Neuroestrogen, rapid action of estradiol, and GnRH neurons. Front Neuroendocrinol 2012;33:364-375.

97 Zwain IH, Yen SS: Neurosteroidogenesis in astrocytes, oligodendrocytes, and neurons of cerebral cortex of rat brain. Endocrinology 1999;140:3843-3852.

98 Azcoitia I, Yague JG, Garcia-Segura LM: Estradiol synthesis within the human brain. Neuroscience 2011;191:139-147.

99 Jung H, Carmel P, Schwartz MS, Witkin JW, Bentele KH, Westphal M, Piatt JH, Costa ME, Cornea A, Ma YJ, Ojeda SR: Some hypothalamic hamartomas contain transforming growth factor alpha, a puberty-inducing growth factor, but not luteinizing hormonereleasing hormone neurons. J Clin Endocrinol Metab 1999;84:4695-4701. 
100 Baroncini M, Jissendi P, Catteau-Jonard S, Dewailly D, Pruvo JP, Francke JP, Prevot V: Sex steroid hormones-related structural plasticity in the human hypothalamus. Neuroimage 2010;50:428-433.

101 Hemrika DJ, Slaats EH, Kennedy JC, de Vries Robles-Korsen TJ, Schoemaker J: Pulsatile luteinizing hormone patterns in long term oral contraceptive users. J Clin Endocrinol Metab 1993;77:420-426.

102 Urenjak J, Williams SR, Gadian DG, Noble $\mathrm{M}$ : Proton nuclear magnetic resonance spectroscopy unambiguously identifies different neural cell types. J Neurosci 1993;13:981989.

103 Manganas LN, Zhang X, Li Y, Hazel RD, Smith SD, Wagshul ME, Henn F, Benveniste $H$, Djuric PM, Enikolopov G, Maletic-Savatic M: Magnetic resonance spectroscopy identifies neural progenitor cells in the live human brain. Science 2007; 318:980-985.

104 Piet R, Vargova L, Sykova E, Poulain DA, Oliet SH: Physiological contribution of the astrocytic environment of neurons to intersynaptic crosstalk. Proc Natl Acad Sci USA 2004;101:2151-2155.
105 Plant TM: A comparison of the neuroendocrine mechanisms underlying the initiation of the preovulatory LH surge in the human, Old World monkey and rodent. Front Neuroendocrinol 2012;33:160-168.

106 Oberheim NA, Takano T, Han X, He W, Lin JH, Wang F, Xu Q, Wyatt JD, Pilcher W, Ojemann JG, Ransom BR, Goldman SA, Nedergaard M: Uniquely hominid features of adult human astrocytes. J Neurosci 2009;29: 3276-3287.

107 Giaume C, Koulakoff A, Roux L, Holcman $\mathrm{D}$, Rouach N: Astroglial networks: a step further in neuroglial and gliovascular interactions. Nat Rev Neurosci 2010;11:87-99.

108 Slezak M, Goritz C, Niemiec A, Frisen J, Chambon P, Metzger D, Pfrieger FW: Transgenic mice for conditional gene manipulation in astroglial cells. Glia 2007;55: 1565-1576.
109 Hanchate NK, Parkash J, Bellefontaine N, Mazur D, Colledge WH, d'Anglemont de Tassigny X, Prevot V: Kisspeptin-GPR54 signaling in mouse NO-synthesizing neurons participates in the hypothalamic control of ovulation. J Neurosci 2012;32:932945.

110 Herde MK, Geist K, Campbell RE, Herbison AE: Gonadotropin-releasing hormone neurons extend complex highly branched dendritic trees outside the blood-brain barrier. Endocrinology 2011;152:3832-3841.

111 Langlet F, Mullier A, Bouret SG, Prevot V, Dehouck B: Tanycyte-like cells form a blood-cerebrospinal fluid barrier in the circumventricular organs of the mouse brain. J Comp Neurol 2013 DOI: 10.1002/cne.23355.

112 Yue J, Mulder KM: Transforming growth factor-beta signal transduction in epithelial cells. Pharmacol Ther 2001;91:1-34.

113 Peles E, Nativ M, Lustig M, Grumet M, Schilling J, Martinez R, Plowman GD, Schlessinger J: Identification of a novel contactin-associated transmembrane receptor with multiple domains implicated in protein-protein interactions. EMBO J 1997;16: 978-988. 